M. clavata Stal the third antennal segment is more slender, the fourth conical, in the long-winged form the costal margins are distinctly curved, not parallel, and the discoidal area extends slightly beyond the middle of the hemielytra; in M. lurida Stal the third and fourth antennal segments are longer, scarcely clavate; and in $M$. uniformis Stal the antennæ are much shorter.

\title{
QUESTIONS OF NOMENCLATURE CONNECTED WITH THE ANT GENUS LASIUS AND ITS SUBGENERA.
}

\author{
By William Morton Wheeler, \\ Bussey Institution, Harvard University.
}

There seems to be no end to the nomenclatorial cataclysms precipitated by men who delight in resuscitating and reëditing musty entomological documents that have been unfortunately spared by the tooth of time to plague those among us who wish to see taxonomy rapidly stabilized so that we may be able to give all our attention to more interesting and important matters. Just as we were beginning to flatter ourselves that a few common insect names in universal use for the greater part of a century must at last be immune from the inroads of the resuscitators we are informed by Morice and Durrant ${ }^{1}$ that our familiar generic name Lasius, which has been borne so long by the common garden ant, probably the most abundant insect of the northern hemisphere, must be consigned to the synonymic limbo and replaced by a new name. The case is so clearly stated by Donisthorpe in his excellent monograph of British ants ${ }^{2}$ that I shall quote his account of it. "Fabricius (Syst. Piez., 415, 1804) published a heterotypical genus Lasius for the reception of ten species of ants, but this use of the name is invalid since Lasius (Type Apis quadrimaculata Panz.) had already been used by Jurine for a genus of bees [Erlangen Litteraturzeitg., 1, 164, No. 33, 1801: Nouv. Méth. Hym., 235238, No. 33, Pf. 4, 33, 11.33. 1807]. Latreille, Gen. Crust.

\footnotetext{
1 The authorship and first publication of the "Jurinean" Genera of Hymenoptera: being a reprint of a long-lost work of Panzer, with a translation into English, and Introduction and Bibliographical and Critical Notes. Trans. Ent. Soc., London, 1914 (1915), pp. 339-436.

2 British Ants, Their Life History and Classification. Plymouth, Wm. Brendon and Son, I.td., 1915, p. 186.
} 
Ins. 4.126 (1809) sunk Lasius F. as a synonym of Formica, and the Fabrician name ceased to be used till 1861, when Mayr (Europ. Formicid., 49, 1861) revived and recharacterized Lasius F., adopting niger L. as his type. Bingham Faun. Brit. India. Hym. 2, 338 (1903) and Wheeler Ann. New York Acad. Sc., 21, 165 (1911), also cite niger as the type. This species was also adopted as the type by Morice and Durrant Trans. Ent. Soc., London, 1914, 9, 421-423 (1915), who gave the following reasons for the change of the name: "In the Systema Piezatorum Fabricius made use of Jurine's name Lasius but applied it to a genus of ants which he separated from Formica L. and later authors have ignored Jurine's Lasius, no doubt because the publication of the Piezatorum (1804) antedates that of the Nouvelle Méthode (1807). But the real date of Lasius Jrn. as we now learn, is May 30, 1801 (Erlangen list), § Lasius F. (1804) therefore sinks as a homonym of the earlier Lasius Jrn. A new name for Lasius F. is necessary; there being apparently no existing synonym, we therefore propose that it be called Donisthorpea in recognition of Mr. H. St. J. K. Donisthorpe's careful investigations into the bionomics of this and other Heterogynous genera."

A study of Morice and Durrant shows that the article which they unearthed in the Erlangen Litteraturzeitung of 1801 was published anonymously, but that in a footnote to page 7 of the Kritische Revue of 1806 Panzer admitted that he was its author. It is clear, furthermore, that Panzer cited Lasius and several other Hymenopterous genera as Jurine's. My friend Professor Cockerell writes me that he regards the Panzer article as having no taxonomic status both because it was published anonymously and because it did not appear in a scientific journal. I incline to agree with him, though I am compelled to admit that the publication of the genera as Jurine's and not as those of the anonymous author may put a different construction on the matter. This evidently determined Morice and Durrant to accept Lasius and certain other genera as being valid and as antedating those of Fabricius. So far as I am able to learn, cases of this kind are not specifically provided for in our various nomenclatorial codes.

Accepting for the moment the correctness of Morice and Durrant contention that Lasius Jurine must supplant Anthophora among the bees and that the genus Lasius Fabr. must be renamed, 
we may next inquire whether the introduction of the name Donisthorpea was justified. Little study of the history of the ant genus Lasius is needed to establish the fact that there are at least three other names, each of which would take precedence of the one suggested by the authors under consideration. In 1840 Shuckard $^{1}$ gave the name Formicina to a genus, which according to his statement contained what we now call Formica rufa and Lasius flavus, so that if no resuscitator succeeds in exhuming some other name suggested between 1807 and 1840, Formicina should be chosen to replace Lasius Fabr., with L. flavus as the type. Shuckard evidently selected the large Formica herculeana L. as the type of his genus Formica (our present Camponotus) and placed the smaller species, which we now assign to Formica and Lasius, in his genus Formicina. A second name Acanthomyops, was proposed by Mayr in $1862^{2}$ for the North American Lasius claviger Roger. This name has since been retained as that of a subgenus characterized by three-jointed instead of six-jointed maxillary palpi in the worker and female. Ruzsky, ${ }^{3}$ in 1913, recognized two additional subgenera: Dendrolasius and Chthonolasius, the type of the former being L. fuliginosus Latr.; that of the latter, L. flavus L. Chthonolasius, therefore, falls as a synonym of Formicina Shuckard, but even Dendrolasius would take precedence of Donisthorpea. If, however, Formicina takes the place of Lasius as a generic name, the genotype must be shifted to L. flavus, a species belonging to what is now a different subgenus, so that Donisthorpea could be retained as the name of a subgenus with $L$. niger as the type. The genus would then have the following composition:

Genus Formicina Shuckard (=Lasius Fabr.).

Genotype: Formica flava L.

Subgenus Formicina Shuckard (=Chthonolasius Ruzsky).

Subgenotype: same as the genotype.

Subgenus Donisthorpea Morice and Durrant (=Lasius auct). Subgenotype: Formica nigra L.

Subgenus Dendrolasius Ruzsky. Subgenotype: Formica fuliginosa Latreille.

\footnotetext{
1 In Swainson and Shuckard's "On the History and Natural Arrangements of Insects," Longman, Orme, etc., London, 1840.

2 Verh. zool. bot. Ges. Wien, 12, 1862, p. 699.

8 Myrmekologische Notizen. Arch. f. Naturg., 79, 1913, pp. 58-63, 3 figs.
} 
Subgenus Acanthomyops Mayr. Subgenotype: Lasius claviger Roger.

While discussing Morice and Durrant's work in a recent paper ${ }^{1}$ Forel contends that Acanthomyops Mayr. should replace Lasius Fabr. He therefore cites the genus and its subgenera thus:

“Genre Acanthomyops Mayr. (1862).

$=$ Lasius F. 1804 (non Jurine 1801).

=Donisthorpea Morice et Durrant.

Type: claviger Roger.

Subgen.: Chthonolasius Ruzsky.

Type: niger L. (flavus ex Ruzsky).

Subgen.: Dendrolasius Ruzsky.

Type: fuliginosus Latr."

This arrangement seems to me to be inadmissible, first, because Forel has no right to change the type of the subgenus Chthonolasius from L. flavus to L. niger, and second, because these two forms, in my opinion, represent distinct subgenera, Chthonolasius $(=$ Formicina) being sufficiently characterized by the shape of the maxillary palpi of the female and worker, the vestigial eyes of the worker and the hypogæic mode of life. In the two latter characters the species of Chthonolasius resemble those of Acanthomyops and not niger and its allies. As an after-thought, however, Forel appends the following postscript: “Mr. Emery m'écrit qu'à son avis il vaudrait mieux prendre pour Lasius le nom nouvellement deterré par Wheeler de Formicina Shuck., nom en partie basé sur le Lasius flavus. Je n'ai rien à y opposer, pourvu qu'on finisse une bonne fois avec ces déménagements perpétuels des anciens noms." I infer, therefore, that he now favors an arrangement like that given above (p. 170) with Formicinaas the genus, but with Donisthorpea eliminated and its species included in the subgenus Formicina.

For the present I propose to be conservative and to retain Lasius Fabr., because the status of Panzer's Erlangen list seems to me to be very dubious and because I sympathize with those entomologists who decline to abolish generic names in universal use for more

1 Fourmis du Cogo et d'autres provenances ı́écoltées par M. M. Hermann Kohl, Luja, Mayne, etc. Rev. Suisse Zool. 24, 1916. p. 460. 
than half a century. I therefore suggest the following as a satisfactory arrangement of our North American forms of Lasius: ${ }^{1}$

Genus Lasius Fabr.

Subgenus Lasius Fabr. (=Donisthorpea Morice and Durrant)

niger L. var. sitkaënsis Pergande.

Var. neoniger Emery.

Subsp. alienus Forster var. americanus Emery.

Subgenus Formicina Shuckard (=Chthonolasius Ruzsky). flavus L., subsp. nearcticus Wheeler.

Subsp. claripennis Wheeler (in MS.).

brevicornis Emery.

Subsp. microps Wheeler (in MS.).

umbratus Nylander subsp. subumbratus Viereck.

Subsp. mixtus Nyl. var. aphidicola Walsh.

Subsp. vestitus Wheeler.

Subsp. speculiventris Emery.

Subsp. minutus Emery.

humilis Wheeler (in MS.)

Subgenus Acanthomyops Mayr.

claviger Roger.

Subsp. subglaber Emery.

interjectus Mayr.

Subsp. mexicanus Wheeler.

Subsp. coloradensis Wheeler (in MS.).

Subsp. arizonicus Wheeler (in MS.).

Subsp. californicus Wheeler (in MS.).

occidentalis Wheeler.

murphyi Forel.

latipes Walsh.

\section{Postscript.}

Since the preceding article was sent to the Editor of Psyche, I have received from Professor Emery a paper (Formiche d'Italia nuove o critiche. Rend. R. Accad. Sc. Ist. Bologna 12 Marzo,

\footnotetext{
1The subgenus Dendrolasius, which should include besides the subgenotype L. fuliginosus, the peculiar Japanese L. spathepus Wheeler, is confined to Eurasia and is therefore omitted.
} 
1916, pp. 53-66, 7 figs.) in which he discusses the synonymy of Lasius and its subgenera. He accepts Jurine's Lasius as valid and substitutes Formicina Shuckard for Lasius Fabricius, presenting the same arrangement of the subgenera and their types as I have given on page 170. I am still unable to take this view of the matter, because I am not convinced that the generic name of another author (in this case Jurine) is valid when cited in an anonymous paper which itself has no taxonomic status. It would seem that if an anonymous author later acknowledges the authorship of his paper, the validity of the latter should date only from the time of this acknowledgment. If this rule were followed, Lasius Jurine would date from 1806 and could not replace Lasius Fabricius of 1804.

\section{A PHOSPHORESCENT ANT.}

\section{By William Morton Wheeler, Bussey Institution, Harvard University.}

Mr. George P. Engelhardt, curator of the Division of Invertebrates of the Brooklyn Museum, recently sent me the following letter and the ant to which it refers:

\section{"My dear Prof. Wheeler:}

"San Francisco, Calif., Aug. 8, 1916.

"One of my most interesting days on the Pacific Coast this summer was spent with Fordyce Grinnell on a thirty-mile tramp through the Sierra Madre, July 28. Starting from Pasadena we followed the Arroyo Seco to the Divide, came up around Mount Gabriel (6,150 feet) and reached Mount Lowe (5,650 feet) in time for a glorious sunset. Our descent from Mount Lowe was made over the steep and winding ridge trail after dark. There was no moon, but a star-studded sky, while 5,000 feet below Pasadena and Los Angeles had been transformed into a sea of sparkling lights.

"Down at about the 4,000 feet level we stopped before a bright spark rapidly crossing the trail. Expecting to find one of the Lampyrids, or fireflies, which Grinnell told me were uncommon in the region, we struck a match and to our surprise found an ant. Neither of us had heard of phosphorescent ants before. In a 

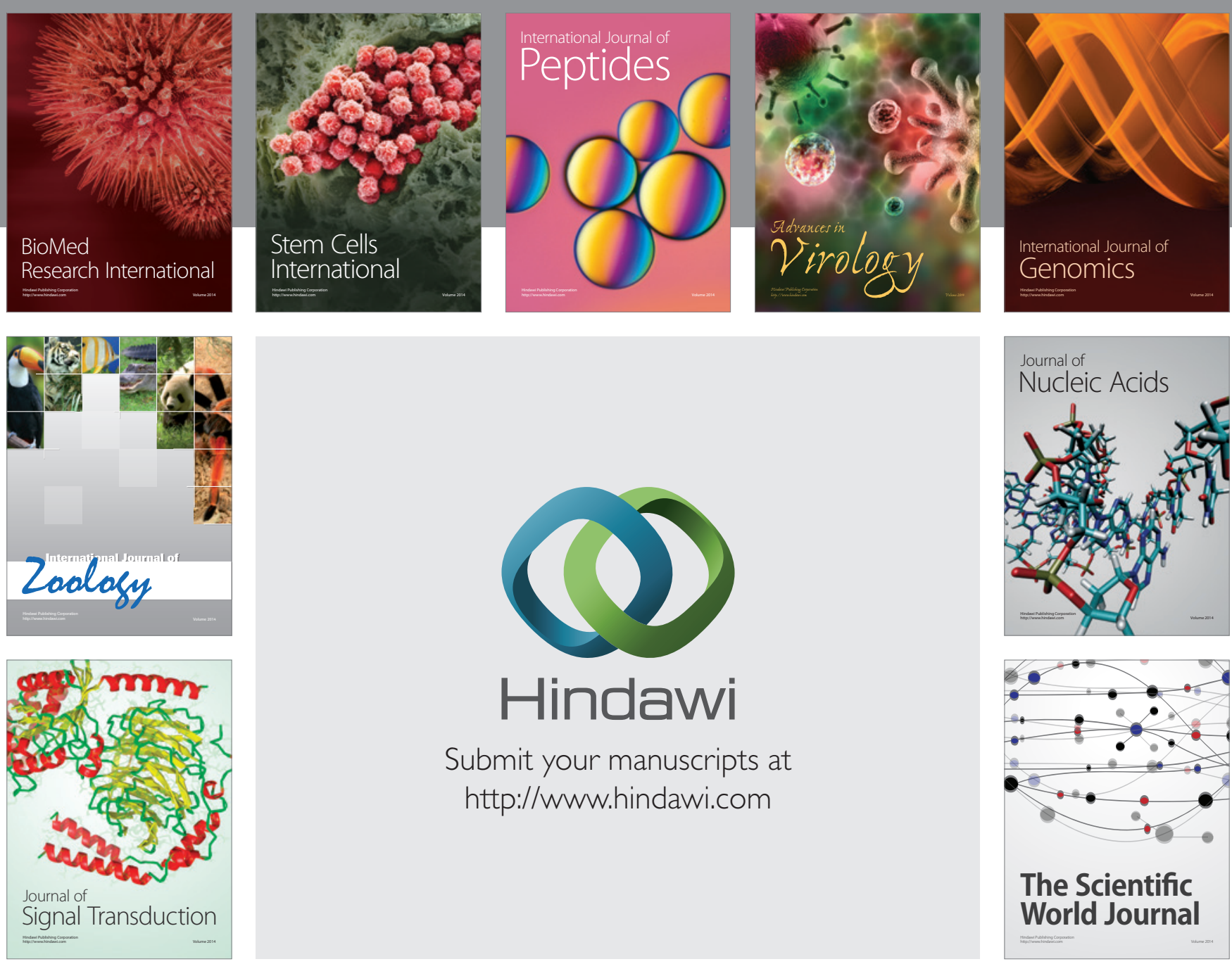

Submit your manuscripts at

http://www.hindawi.com
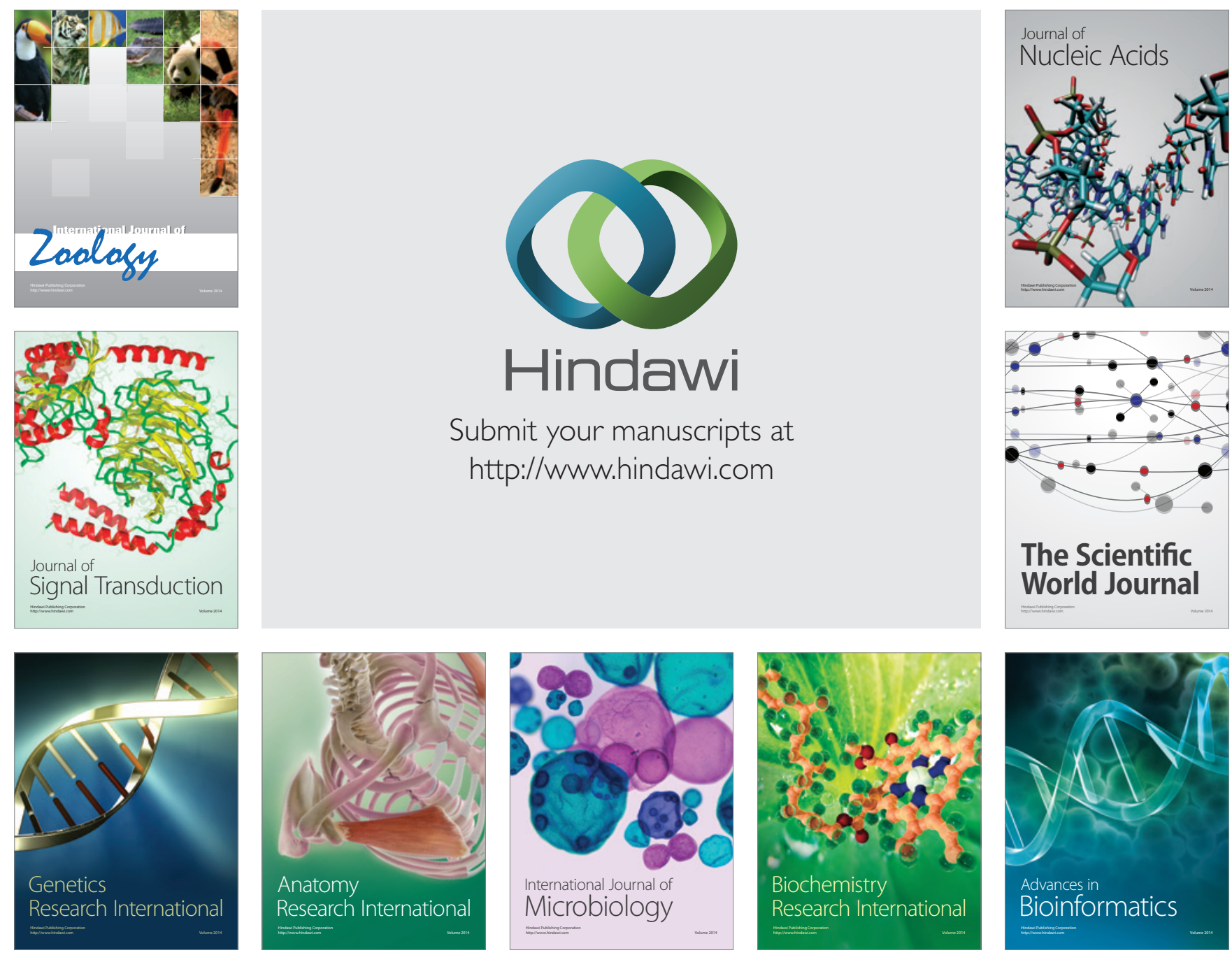

The Scientific World Journal
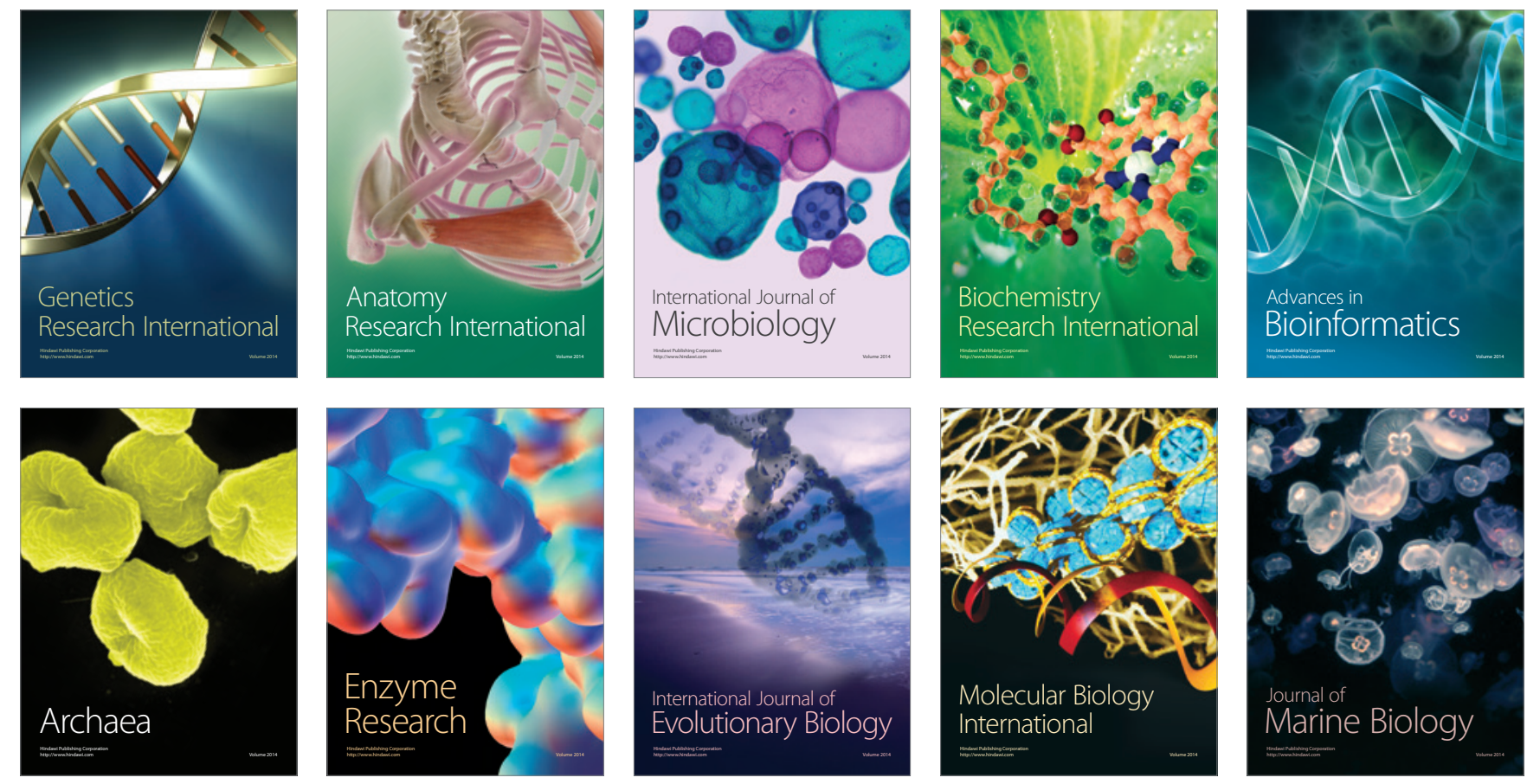